\title{
INTRODUCTION: IN TERMS OF ATHENS
}

\section{Johanna Hanink and Demetra Kasimis}

Athens, again? Classicists have long issued frustrated reminders that there was a great deal more to Greek antiquity than 'classical Athens'. At the beginning of the fifth century вСE, Athens was but one of roughly 850 distinct Greek poleis that together constituted the Greek world, ${ }^{1}$ and the famed Athenian democratic experiment came to an end in the fourth, less than two centuries after it began. And yet none of those ancient Greek states is so richly attested as Athens, and it is Athens that continues to exert the firmest grip on the public imagination, especially during times of political convulsion. The last year alone has seen countless think-pieces on Thucydides' account of the plague of $430 \mathrm{BCE}$, ominous invocations of the Platonic notion that tyranny is an outgrowth of democracy run amok, critically acclaimed web-based performances of Theater of War's Sophocles-inspired Antigone in Ferguson, and a flurry of commemorative events both in Greece and abroad around the 2,500th anniversary of the Battles of Thermopylae and Salamis.

But despite its persistent presence in the public imagination, Athens seems to have fallen somewhat out of fashion within the academic field of Classics. Of the 157 dissertations-in-progress reported to the Society for Classical Studies in 2017-18 (the most recent year for which data is published), only a dozen or so appear to have been centered on classical Athens and texts-tragic, comic, historiographical, philosophical, epigraphical, or otherwise-born of the Athenian democratic milieu. ${ }^{2}$ Athenian works continue to be read in translation in university-level courses on philosophy, politics, literature, and others, and yet it can be difficult to locate Greek texts and commentaries suitable for undergraduates on works that, in earlier centuries, had formed the core of university instruction. (Isocrates' Panegyricus and Xenophon's Cyropaedia mark two examples of 'core' Athenian texts that are hardly easy to assign to Greek-learners today.) At the same time that interest in Athens has contracted in Classics, the field has expanded in salutary ways: recent decades have seen a reorientation to the literary production, material culture, and historical questions of other places and eras-from Hellenistic Alexandria to the Hellenized world of the 'Second Sophistic' and beyond.

As we scanned this shifting academic and political landscape with the public's interest in Athens firmly in view, we wanted to reflect on where and how political

1. Hansen (2003), 263f. (thesis 23); Hansen notes that it can be presumed that there were altogether ca. 1,500 poleis, but not all at the same time'. Hansen and Nielsen (2004) feature 1,035 entries in their inventory of Greek Classical poleis.

2. https://classicalstudies.org/education/list-progress-and-completed-dissertations-classics\#2017. 


\section{JOHANNA HANINK AND DEMETRA KASIMIS}

and theoretical work on Athens is taking shape today. It has been more than a half-century since the 'structuralist invasion' of the so-called Paris School reached American shores and breathed new life into the Athenian archive. ${ }^{3}$ Scholars associated with that informal school-Jean-Pierre Vernant, Pierre VidalNaquet, Marcel Detienne, Nicole Loraux, and others-changed the way that Anglophone classicists approached the Athenian material. They introduced the concept of the social 'imaginary' to the study of Athenian history and literature; they argued that Athenian tragedy questioned even as it celebrated the city's structures and institutions, ${ }^{4}$ and showed us how the deaths of soldiers provided occasions for the city of Athens to construct and praise an image of itself that still holds sway today. ${ }^{5}$ Vernant credited the success of Athenian tragedy to its 'historical moment', and he and his colleagues explored the workings of that moment with great detail and subtlety. ${ }^{6}$ But many of these structuralist and post-structuralists were also responding implicitly to the political conflicts of the postwar and postcolonial contexts in which they lived. If the Paris School took a philological and historical turn to Athens, it was because they aimed to engage in 'a new interrogation of the political', as Miriam Leonard has argued. ${ }^{7}$ Do today's theoretically minded readers of democratic Athens share a similar critical impulse, or has this other 'historic' moment come to an end, too?

Classicists, of course, are not the only scholars with stakes and interests in the classical Athenian legacy, and some of the strongest and most critical engagements with this afterlife are to be found in the field of political theory. Athens' literary and cultural production continues to inspire a whole abecedary of contemporary political theorists and philosophers, from Giorgio Agamben to Judith Butler to Adriana Cavarero and beyond. Each year, the program of the Association for Political Theory conference (and even of the American Political Science Association) vies with that of the Society for Classical Studies for sheer quantity of papers on Athenian authors and subjects. Indeed, it is striking that, at a time when narratives about the 'Greek' or even the 'Athenian Miracle' and the city's notional status as the spiritual birth of 'Western Civilization' are rightly coming under scrutiny and being dismantled, political theorists continue to think, play, and experiment with Athens and its legacies in order to advance radical critiques of (democratic) inequality and oppression. The Athenians were not inherently made of miraculous or ingenious stuff. They were, however, exceptionally committed to debating with each other, documenting themselves, and to projecting a civic identity in media that have managed to survive to the present day. They were also unusually skilled at convincing others that their city and civic community were extraordinarily special, and

\footnotetext{
3. See Stocking (2020).

4. e.g. Vernant (1972); Vernant and Vidal-Naquet (1972).

5. Loraux (1981).

6. See Vernant (1972) on 'Le moment historique de la tragédie en Grèce'.

7. Leonard (2005).
} 


\section{INTRODUCTION}

that its memory was truly worth preserving, studying, and celebrating. The result is that the archive of evidence for classical Athens offers an unusually high-resolution picture of one ancient community's set of political questions and concerns, and of the host of imaginative ways in which its members went about asking and addressing them.

For this special volume of Ramus, we wanted to showcase the work of scholars who are bringing fresh political and theoretical questions to Athens and its legacies. We coupled classicists with political theorists and asked each pair to write separate original essays on a 'term' that captured an enduring or contemporary political concern. Kasimis, Abolafia, Moro, and Fisher all earned their PhDs in Political Science Departments (Simonton earned his MA in Political Science at Stanford, while a PhD student in Stanford's joint program of Classics and Philosophy), while Lape, Folch, Coo, Hanink, and Clements were all trained more explicitly in the study of antiquity (Clements earned her $\mathrm{PhD}$ in the History of Art). By pursuing this structure, we wanted to inspire our contributors to enact and embrace one of the hallmark features of the ancient Athenian texts: dialogue. That dialogue is by no means limited to, say, Plato's or Xenophon's formal Socratic dialogues. Rather, by dialogue we mean a long, broad, and multivocal conversation in which the entire Athenian corpus is engaged: dialogue among the tragedians, between the comic and tragic playwrights and philosophers, between drama and the funeral orations, between Athens' civic architecture and oratory, and so on.

Each pair of authors remained in touch throughout the writing process-an activity that took place against the backdrop of the coronavirus epidemic, repeated manifestations of systemic anti-black racism, the \#MeToo movement, and the continued erosion of American democratic institutions. The essays are marked by these political realities and their vicissitudes in ways both subtle and overt. In one regard, we could not have predicted what our experiment has yielded: it can be difficult to distinguish between the classicists and political theorists on the basis of their essays alone. Not unlike the structuralists of the postwar period perhaps, here classicists return to Athens through the mediation of theorists writing on antiquity, while political theorists take up contemporary concerns through a heightened sensitivity to matters of philology and archaeology. The result is a series of diptychs orbiting around the thought and politics of classical Athens, and a collection of essays that strives to interrogate, destabilize, and reimagine the terms that serve as its conceptual anchors.

\section{Mobility}

For Demetra Kasimis and Susan Lape, dramatic poetry invites deep critical engagement with the difficult question of women's dislocation. Migration and exile emerge as unavoidable political eventualities for women in the plays the authors take up. At the same time, women's movement is shown to be nearly 


\section{JOHANNA HANINK AND DEMETRA KASIMIS}

impossible to classify within the conventional political terms of the time, which leads to their creative and critical redeployment and figuration. If women in the polis are asymmetrically exposed to precariousness, as Kasimis and Lape both suggest, what is it about the polis order that makes their vulnerability at once inevitable yet hard to capture? Both authors argue that conventional identitybased categories are inadequate for making visible the political experiences of precarity and exile to which women are uniquely vulnerable-tragedy and comedy throw light on these experiences by refiguring existing political idioms and classifications. They show in different ways that women's (forced) mobility cannot be understood apart from a discussion of their agency, sexual labor, and reproduction, which are typically depoliticized. In Kasimis' reading of Electra ('Electra Lost in Transit'), Euripides' protagonist dares to declare not only that she has been aberrantly moved between homes, but that this traffic-gonewrong amounts to a forced migration-she is ambiguously a wife and this makes her an immobilized phygas. But Electra does not simply gender exile, Kasimis argues. In refusing to think of displacement in exclusively territorial and spatial terms, Electra transforms the meaning of phygas in general. Lape ('Mobility and Sexual Laborers in Menander's Dis Exapaton and Plautus' Bacchides') finds that comedy is an understudied resource for exploring the situation of female economic migrants in particular. She homes in on the figure of the hetaera, whose freedom is importantly represented as a double bind, as newly danger-inducing for its practitioner as it is newly empowering.

\section{Incarceration}

At the heart of this volume is the sense that the marginal-as a position or an interpretive approach-is central to political analysis. Shifting us, at least ostensibly, from mobility to immobility, the essays by Marcus Folch ('Red Figure Is the New Black: The Imprisonment of Women in Classical Athens') and Jacob Abolafia ('Plato's Theory of Incarceration') consider the unseen both figuratively and literally in their attention to the democratic uses of imprisonment. Like those of Kasimis and Lape, Folch's essay weaves together issues of gender and deviance. It begins with the surprising observation that the question whether women were incarcerated in democratic Athens, however difficult to locate historically, is rarely if ever posed by classical scholarship. This lack of interest, Folch argues, is a sign of a 'male-centric bias' pervasive in current work on incarceration. Contemporary critics generally assume that the male inmate is not a gendered category but a universal figure that can stand in for the inmate tout court. The possibility that Athens created the means for incarcerating women but appears not to have used it frequently is vital to consider, Folch argues, because it ultimately raises a deeper question about how Athenians imagined the political function of imprisonment. Theirs was not a punitive or remediative institution, Folch maintains, but an intermediary stop along the 


\section{INTRODUCTION}

way to execution. This is key, for susceptibility to execution depends on the holding and losing of (male) membership privileges. Abolafia, too, is interested in the creation of prisons in classical Athens, yet his focus falls on how thinkers like Plato contest the role that institution should play. After clarifying how Athenian notions of carceral punishment differ from the modern idea of the penitentiary theorized by Foucault, Abolafia ultimately finds that Plato's notion of penal confinement is nevertheless a disciplining tool of citizen reform. On display here is Plato's reappropriation of democratic tools - an example of 'democratic entanglement', to borrow Sara Monoson's expression. ${ }^{8}$ Remedial education can be redeployed for non-democratic purposes, its contours dictated by what reason demands rather than the interests of the rulers.

\section{Sisterhood}

In seeking new paradigms of mobility, Kasimis and Lape had both turned to the Athenian dramatic archive. A concern with dramatic representations of women also motivates the essays by Lyndsay Coo ('Shifting Sisterhood: Electra and Chrysothemis in Sophocles' Electra') and Valentina Moro ('Sailing Together: The Agonistic Construction of Sisterhood in Sophocles' Antigone'), which center on representations of sisterhood in Sophoclean tragedy. Both Coo and Moro challenge the notion that the Sophoclean conception of sisterhood depends on an asymmetry between a 'stronger' sister (Antigone, Electra) and a 'weaker' one (Ismene, Chrysothemis). Coo demonstrates the generative potential of applying new theoretical frameworks that recognize 'collaborative, conspiratorial, and covert forms of resistance as valid political action' to Sophoclean drama. In the conflict between the sister-pair staged by Sophocles' Electra, she reads Electra and Chrysothemis as articulating different visions of the responsibilities of kinship. Whereas Electra is fixated on her male kin, the nature of Chrysothemis' repeated efforts to reach out to her suggests a conception of sisterhood that resonates with the contemporary feminist account of female solidarity. Coo's analysis further destabilizes the tired 'tragic hero' paradigm so often ascribed to Athenian tragedy by showing how Electra encodes a model of collaborative resistance and partnership in political action. Moro's investigation of the sororal kin relationship between Antigone and Ismene likewise suggests that both speakers understand sisterhood as a process rather than a static state. Here Moro draws upon Bonnie Honig's account of 'agonistic sisterhood' and argues that, over the course of the play, Antigone and Ismene become sisters, as from their agonistic encounters a new bond emerges that is forged of language and based on a mutual understanding of the pair's shared responsibilities to both kin and city. The fine-grained readings

8. Monoson (2000). 
performed by both Coo and Moro speak to the complexities of the sororal kinship relation as depicted and interrogated in the Sophoclean plays, and both demonstrate the potential rewards of returning to Athenian drama with a combination of the theorist's imagination and the philologist's toolkit.

\section{The Body Politic}

Whereas Coo and Moro consider the dynamics and potentialities of kinship bonds, Simonton and Hanink re-examine aspects of the civic bond and the space that it occupied in the Athenian cultural and political imaginary. Both of these contributors are particularly interested in setting prose and poetry sources alongside each other in an effort to reconstruct ancient Athenian constitutional poetics. Simonton's essay ('Representing the Demos: Adapting Insights from the Constructivist Turn in Political Representation') demonstrates how recent constructivist approaches to political representation as a give-and-take process between political actors and citizen-audiences open exciting new inroads into the study of ancient democracy. In exploring the constructivist paradigm, according to which political representation emerges from an ongoing process of identity formation (a process that in some ways echoes the ongoing forging of sisterhood described by Moro), Simonton raises several examples from Athenian sources that speak to instances in which 'the will of the people' was only retroactively hailed into being and thus determined post eventum. By means of two substantive case studies centered on the figures of Demosthenes and Cleon, Simonton argues that orators' rhetorical descriptions of the demos were, like personifications of the demos in visual media, also 'artistic creations' designed to elicit affect and action from their public. Hanink also takes up the Athenian evidence for personification of the demos - and the specific case of Aristophanes' Knights - as part of an essay ('Was the polis a Person in Classical Athens? Civic Bodies and Choral Politics in the Theater') that seeks to clarify both the possibilities and limitations of the modern 'state personhood' paradigm in its potential applications to classical Athens. Her case studies, all drawn from the world of the theater, suggest that the Athenians did not admit of a personification of their polis that is wholly compatible with today's notions of 'state actors' and 'state persons'. Like Simonton, Hanink proposes that the theater preserves a valuable archive of evidence for the logic of Athenian political identity.

\section{Civic Identity}

The paired authors of our final diptych consider further strategies by which the Athenians constructed, imagined, and projected their ethnopolitical identity. Both of these essays also happen to call into question the logocentrism of standard political theory approaches to classical Athens-and of the preceding papers in 


\section{INTRODUCTION}

this volume-by demonstrating the material record's power to speak and bear witness to points about which our texts are comparatively silent. Whereas Hanink had insisted upon the importance of the theater as a source for the Athenian stage imaginary, Fisher issues an explicit plea ('Heroic Democracy in High Relief: Political Legitimacy and Monumental Imagery in Fifth-Century Athens') that theorists turn more often to the evidence of 'democratic visual culture'. The 'public monuments, political optics, and civic spaces' of Athens shaped and reflected political understanding, and Fisher submits that this dossier of evidence provides an alternative perspective on standard narratives about the practical dynamics of the transition to democracy and the relocation of power within the demos. The visual idiom of the early democratic monuments showed a surprising degree of continuity from the period of elite rule, which in turn sheds light on the strategies by which the demos projected its sovereign legitimacy_often in 'tyrannical' visual terms. Clements, too, finds evidence in the visual record for aspects of the Athenian political imagination that are not fully elaborated in contemporary written sources ('The Gift of Identity: (Re)presenting Autochthony in Classical Athens'). Turning from the monumental scale of public architecture to the human scale of ceramic vessels, Clements discusses how fifthcentury vase painting, by far the most extensive early surviving record for the concept of autochthony, figures the Athenians' autochthonous status and identity as a literal gift from the gods. Though autochthony appears to have been a core premise of Athenian ethnopolitical identity, autochthony narratives are surprisingly little elaborated in fifth-century texts.

In juxtaposing these voices, we strive to stage a dialogue from practitioners formally trained in disciplines that are formally cordoned off from each other but which both, particularly throughout the second half of the twentieth century, engaged in lively and explicit discussion over the meaning of 'politics', the place of critique, and the historical and symbolic functions of Athenian democracy. ${ }^{9}$ All the essays in this volume ultimately draw on scholarship from both Classics and Political Theory, and in so doing they invite us to consider what forms this interdisciplinary dialogue is taking today, and what potential there is for forging a common future. Under what conditions do (can, ought) classicists look to political theory? When and how do (can, ought) political theorists deploy classical scholarship?

Each of the contributors to this volume returns us to classical Athens, late modernity's most privileged site for theorizing the political, not to take it for granted but to illustrate its critical promise. One of the most striking features of the Athenian corpus is its constant ability to yield up new insights to its modern interpreters - or rather (to put it the other way around), its interpreters'

9. For an overview see Kasimis (2015). 


\section{JOHANNA HANINK AND DEMETRA KASIMIS}

perennial willingness to pose new questions to these ancient texts. The 'terms' of this volume were determined by some of the most pressing current political issues and questions, yet even when approached from contemporary vantage points Athens, we find, still has more to say and further perspectives to add. Still, a critical outlook remains necessary, even as what 'Athens' signifies shapeshifts over time. How do we participate in a multi-millennia conversation while criticizing and transforming its terms? This special volume is an experiment that attempts to think through these challenges, and to think through them together. What emerges again and again in both the individual essays and the paired diptychs is the sense that an expansive 'canon' of Athenian political thought has the potential to speak in new ways to the insistent questions of collective life.

Brown University

johanna_hanink@brown.edu

University of Chicago

demetrakasimis@uchicago.edu

\section{BIBLIOGRAPHY}

Hansen, M.H. (2003), '95 Theses about the Greek Polis in the Archaic and Classical Period', Historia 52, 257-82.

Hansen, M.H., and T.H. Nielsen (2004), An Inventory of Archaic and Classical Poleis (Oxford).

Kasimis, D. (2015), 'Greek Literature in Contemporary Political Theory and Thought', Oxford Handbooks Online. https://doi.org/10.1093/oxfordhb/9780199935390.013.40.

Leonard, M. (2005), Athens in Paris (Oxford).

Loraux, N. (1981), L'invention d'Athènes. Histoire de l'oraison funèbre dans la 'cité classique' (Paris).

Monoson, S.S. (2000), Plato's Democratic Entanglements: Athenian Politics and the Practice of Philosophy (Princeton).

Stocking, C.H. (2020), "The "Paris School" and the "Structuralist Invasion" in North America', Cahiers 'Mondes Anciens' 13. https://journals.openedition.org/mondesanciens/2739.

Vernant, J.-P. (1972), 'Le moment historique de la tragédie en Grèce', in Vernant and Vidal-Naquet (1972), 13-17.

Vernant, J.-P., and P. Vidal-Naquet (1972), Mythe et tragédie en Grèce ancienne (Paris). 